\title{
Seedling Diversity Considerably Changes Near Localities in Three Salinity Zones of Sundarbans Mangrove Forest, Bangladesh
}

\author{
ASM Helal Siddiqui', Md. Masudur Rahman², Md. Najmus Sayadat Pitol1*, Md. Akramul Islam¹, \\ Sk Md. Mehedi Hasan ${ }^{1}$ \\ 1) Mangrove Silviculture Division, Bangladesh Forest Research Institute, Muzgunni, Khulna-9000. \\ 2) Bangladesh Forest Research Institute, Sholoshohor, Chittagong-4000. \\ * Corresponding author, email: najmus.sayadat@gmail.com
}

Submitted: 12 April 2021; Accepted: 27 July 2021; Published online: 24 September 2021

\begin{abstract}
The status of natural seedlings near localities in the Sundarbans Mangrove Forest was assessed through a stratified random sampling method to observe seedling composition and diversity, importance value index, family importance value, and species evenness. A total of 63 sample plots of $3,990 \mathrm{~m}^{2}$ area were surveyed in three natural and anthropogenic influenced salinity zones of Sundarbans. A total of 16,166 seedlings of 15 species under 12 families were found. Family Euphorbiaceae showed the highest $(59.59 \%)$ family relative density and Rhizophoraceae presented the highest $(20 \%)$ family relative diversity Index (FRDI). The maximum family importance value (FIV) showed by Euphorbiaceae (66.26) and the maximum importance value index (IVI) of species has been observed in Excoecaria agallocha (114.74). Excoecaria agallocha showed the highest relative density $(59.6 \%)$ and relative abundance $(39.87 \%)$ where the highest relative frequency $(15.27 \%)$ was observed by Heritiera fomes. The mean stem density and species diversity index in the whole survey area was 2701 stem ha $^{-1}$ and 0.0009 correspondingly. The Shannon-Wienner's diversity index was 1.52 where the maximum Shannon-Wienner's diversity index was 2.708 . The Simpson's diversity index and Dominance of Simpson index were 0.38 and 0.62 with Simpson's reciprocal index 2.632. The Species evenness index, Menhinick's, and Margalef's indices were $0.561,0.118$, and 1.445 respectively. The Species diversity index of the three salinity zones were $0.0017,0.0029$, and 0.0035 respectively. The ShannonWienner's diversity index of Low Salinity Zone (LSZ), Moderate Salinity Zone (MSZ), and Strong Salinity Zone (SSZ) were 0.887, 1.369, and 1.845 correspondingly where LSZ (0.632) showed the highest Simpson's diversity index follow ed by MSZ (0.394) and SSZ (0.21). The Species evenness index for LSZ, MSZ, and SSZ were 0.346, 0.505, and 0.742 where Menhinick's Index were 0.148 , 0.210 , and 0.207 respectively. The analysis showed poor diversity indices and the area was dominated by few species with few families. The status is also reduced with increasing salinity.
\end{abstract}

Keywords: diversity, evenness, family, importance value, richness, salinity, seedling

\section{INTRODUCTION}

The flora of the Bangladesh tropical forest is one of the ten global hot spot 
zones for biodiversity (Mittermeier et al. 1998) and retains rich biological diversity due to its exceptional geophysical location (Chowdhury 2001; Hossain 2001; Nishat et al. 2002). The forest land and natural forest cover of this country are 1.442 million ha and 1.204 million ha respectively which are managed by the forest department, land ministry, and other individuals (Sobuj \& Rahman 2011). Tropical forests are ecologically and economically important for the livelihood of local communities. For the last few decades, the natural forests of the country are rapidly decreasing at an alarming rate by 1-4\% of their current land area (Laurance et al. 1998) due to overpopulation, land use alterations, unsuitable and poor management practices (Khan 2008). The net forest loss in South and Southeast Asia, from 2010 to 2015 was about 25\% higher compared to 1990 (Keenan et al. 2015) and Bangladesh is also situated in this zone. Agricultural extension, deforestation, extreme removal of woody and non-woody resources, urbanization, and applying unfitted management tools are the major causes of forest degradation in Bangladesh (Hasan \& Alam 2006).

Mangrove forest is one of the most productive vital ecosystems in tropical countries. It provides valuable ecological and economic resources to accelerate sustainable livelihood like nursery grounds, breeding sites for birds, fish, crustaceans, shellfish, reptiles, and mammals with medicinal and aesthetic values (Helal Siddiqui \& Islam 2019). It is also a renewable source of wood, accumulation sites for sediments, contaminants, carbon, and nutrients, while also protect against coastal erosion, cyclones, and tsunami (Paolini \& Sánchez-Arias 2008; Danielsen et al. 2005; Kathiresan \& Rajendran 2005; Badola \& Hussain 2005; Alongi 2002; Mazda et al. 1997). Sundarbans mangrove forest is rich in both floral and faunal diversity compared to other mangroves of the world and it is a suitable place for collecting various minor forest products (Islam et al. 2020) and developing tourism (Dey et al. 2020). Prain (1903) and (Seidensticker \& Hai 1983) recorded 334 species of plants belonging to 245 genera and 75 families where Field (1995) and Tomlinson (1986) included approximately 16-24 families and 54-75 species respectively. In addition, (Karim 1994) reported 123 plant species belonging to 22 families representing 30 genera, and (Helal Siddiqui 2009) reported about 230 species including non-mangroves. Unfortunately, plant species are decreasing gradually due to climatic change, edaphic factors, and various natural and anthropogenic causes. The diminution of native species is hastening at an alarming rate through the quick loss and degradation of forests in Bangladesh (Rahman et al. 2000; Hossain 2001).

Tree diversity, a portray of the natural forest community is fundamental as they offer resources and homes for almost all other forest species (Huston 1994; Richards 1963; Cannon et al. 1998; Hall \& Swaine 1976). For understanding the actions and dynamics of forest ecosystems, the knowledge of the floristic arrangement, their quantitative structure, and diversity are vital (Hossain et al. 2015). Effective conservation measures for sustainable management of forests need an appreciation of phytosociological features of tree species diversity (Feroz et al. 2014; Biswas \& Misbahuzzaman 2008). Natural regeneration of forest tree species should be enhanced by the appropriate artificial and natural process for defending forest flora and continuing sustainability of yield, goods, and services (Haque \& Alam 1988). Potential information for many native tree species is received from various studies that focused on natural regeneration status in different natural forests of Bangladesh (Hossain et al. 2004; Hossain 1999; Hossain et al. 2013; Miah 1999; Motaleb \& Hossain 2007; Rahman et al. 2011; Rahaman et al. 2020).

For formulating a conservation strategy of the forest, quantitative information like regeneration, species composition, and distribution is important (Malik et al. 2014; Malik \& Bhatt 2016; Sharma et al. 2014). The 
range of biodiversity loss in the Sundarbans mangrove forest of Bangladesh is not exactly known due to a very poor database and limited information (Hossain et al. 2004). So, the study of biodiversity is a crucial requisite which is the main objective of this study to effectively protect and manage the existing natural forests for sustainable livelihoods (Hossain et al. 2018; Hossain et al. 2020) for future generations. Some studies were done before in the total area of Sundarbans (Prain 1903; Heining 1892; Helal Siddiqui 2009; Chaffey et al. 1985; Hossain 2003; Rashid et al. 2008; Saiful et al. 2014; Saiful et al. 2015), but this study focused only those areas where various natural and anthropogenic influenced were present. The study was designed to provide quantitative information of the seedling composition, diversity, importance value index, family importance value, species evenness, and compares the diversity indices of three natural and anthropogenic influenced salinity zones in Sundarbans mangrove forest.

\section{MATERIALS AND METHODS}

\section{Study area}

In this study, a total of 21 of 55 compartments were selected randomly which represented the three salinity zones of Sundarbans. The Low Salinity Zone (LSZ) is situated between latitude $22^{\circ} 11^{\prime} 08^{\prime \prime}$ and $22^{\circ} 80^{\prime} 00^{\prime \prime}$ and longitude $89^{\circ}$ $04^{\prime} 44^{\prime \prime}$ and $89^{\circ} 20^{\prime} 31^{\prime \prime}$ and the surveyed compartments were 1, 2, 3, 4, 5, 7, 24, 28 (Figure 1). For the Moderate Salinity Zone (MSZ) the latitude and longitude are between $22^{\circ} 45^{\prime} 13^{\prime \prime}$ and $21^{\circ} 15^{\prime} 22^{\prime \prime}$ and $89^{\circ} 57^{\prime} 10^{\prime \prime}$ and $89^{\circ} 19^{\prime} 59^{\prime \prime}$ respectively and the examined compartments were 15, 21, 30, 31, 32, 35, 36, 37 , and 38. Also, Strong Salinity Zone (SSZ) are located between latitude $22^{\circ}$ $11^{\prime} 08^{\prime \prime}$ and $22^{\circ} 80^{\prime} 00^{\prime \prime}$ and longitude $89^{\circ} 04^{\prime} 44^{\prime \prime}-89^{\circ} 20^{\prime} 31^{\prime \prime}$ and the measured compartments were 46 and 47. All the compartments are located outer part of Sundarbans and near to the localities where natural and anthropogenic influenced are present (Figure 1). The study areas are situated in the warm, humid tropical region. The salinity range of the three zones were $<5 \mathrm{ppt}$ for LSZ, 5-10 ppt for MSZ, and $>10 \mathrm{ppt}$ for SSZ. The minimum and maximum mean annual temperatures are $21^{\circ} \mathrm{C}$ and $30{ }^{\circ} \mathrm{C}$, respectively. The mean annual relative humidity differs from $70 \%$ to $80 \%$ where annual rainfall varies from $1640 \mathrm{~mm}$ and $2000 \mathrm{~mm}$ (Forest Department 2010).

\section{Methods}

A total of 63 sample plots of $3990 \mathrm{~m}^{2}$ (21 sample plots of $1330 \mathrm{~m}^{2}$ area for each salinity zone) area were surveyed followed by a stratified random sampling method in April and May 2019 because most of the phonological behavior (flowering, fruiting, seed dispersal, etc) occurs in April and start to accelerate seed dispersal with seedling recruitment gradually which become more stable gradually to affect seedling diversity. The relative abundance (RA), relative density (RD), relative frequency (RF), and Important Value Index (IVI) were calculated by (Dogra et al. 2009; Nebel et al. 2001; Shukla \& Chandal 2000). Family relative density (FRD) and family relative diversity (FRDI) were calculated by following (Rahman et al. 2011). Various diversity and richness indices were scrutinized by following, (Clifford \& Stephenson 1975; Kent \& Coker 1992; Margalef 1958; Michael 1990; Odum \& Barrett 1971; Pielou 1995; Shannon 1948; Simpson 1949; Whittaker 1977). All the empirical data were calculated with the help of Microsoft Excel 2016. The equations were listed below:

a) Density of a species (D) $=$ (Total no. of individual of a species in all quadrats / Total no. of quadrats studied)

b) Relative density (RD) $(\%)=$ (Total no. of individual of the species / Total no. of individual of all the species) $x 100$ 
Map of The Sundarbans Showing Activities of Mangrove Silviculture Division

Bangladesh Forest Research Institute, Muzgunni, Khulna.

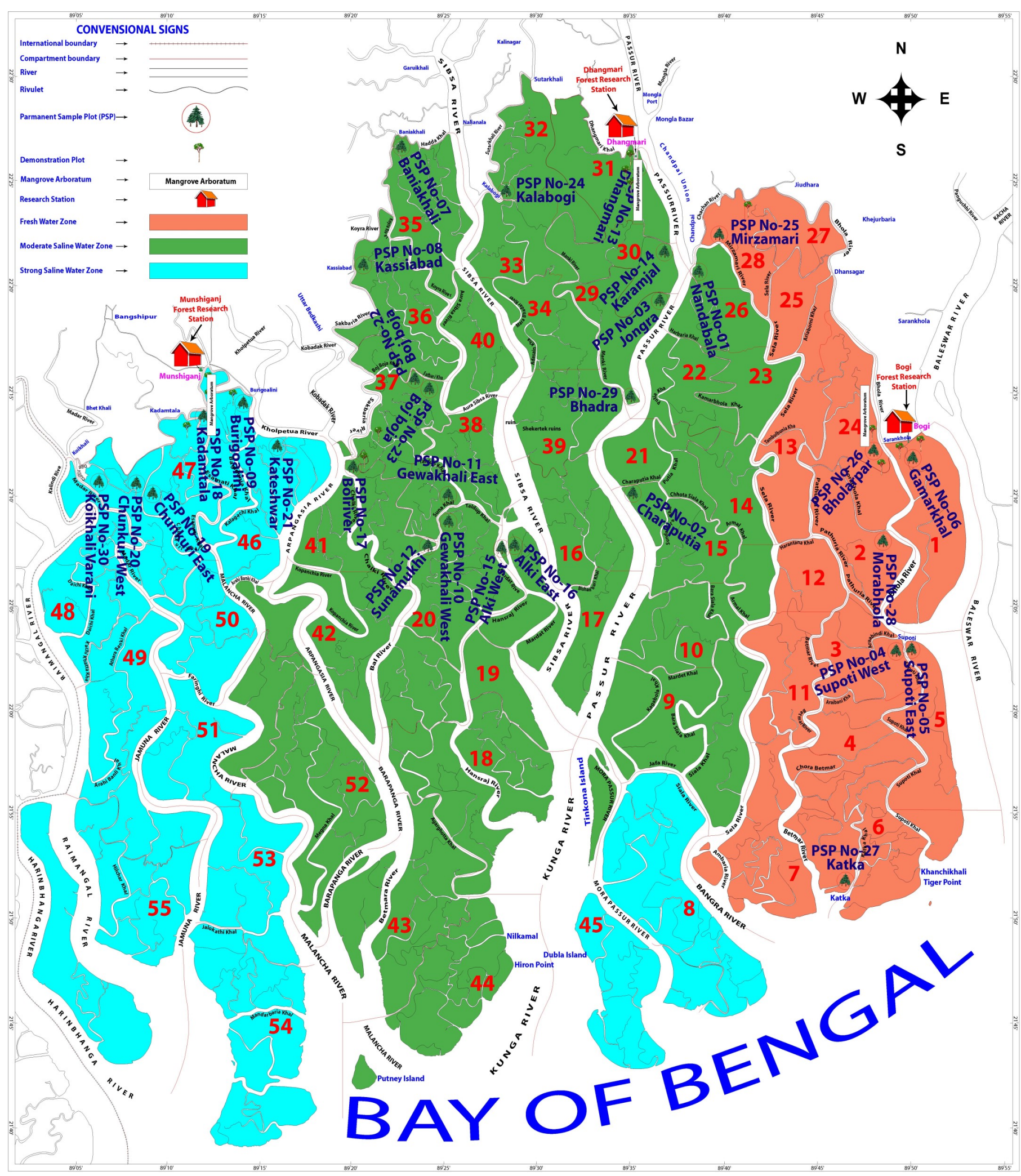

Figure 1. Maps of Sundarbans.

c) Frequency of a species $=($ Total no. of individual of quadrats in which the species occurs / Total no. of quadrats studied)

d) Relative frequency $(\%)=$ (Frequency of one species / Total frequency) $\mathrm{x}$ 100

e) Abundance of a species $(A)=$ (Total no. of individual of a species in all the quadrats / Total no. of quadrats in which the species occurred) 
f) Relative Abundance (RA) $(\%)=$ (Abundance of one species / Total abundance) $\times 100$

g) Importance Value Index (IVI) = Relative Density + Relative Frequency + Relative Abundance

h) Species diversity index $\left(\mathrm{Sd}_{\mathrm{i}}\right)=\mathrm{S} / \mathrm{N}$

i) Margalef's/Species richness index $(\mathrm{R})=(\mathrm{S}-1) / \mathrm{Ln}(\mathrm{N})$

j) Shannon-Wienner's diversity index $(\mathrm{H})=-\mathrm{Pi} \operatorname{In} P i$

k) Shannon's maximum diversity index $\left(\mathrm{H}_{\max }=\mathrm{Ln}(\mathrm{S})\right.$

l) Simpson's diversity index $(\mathrm{D})=(P i)^{2}$

m) Dominance of simpson index $\left(\mathrm{D}^{\prime}\right)=1-\mathrm{D}$

n) Simpson's reciprocal index $\left(D_{r}\right)=1 / D$

o) Species evenness index $(E)=H / \ln (S)$

p) Menhinick's Index $\left(\mathrm{D}_{\mathrm{mn})}=\mathrm{S} / \sqrt{\mathrm{N}}\right.$

q) Family relative density, FRD $(\%)=\left(\mathrm{N}_{\mathrm{f}} / \mathrm{T}_{\mathrm{i}}\right) \times 100$

r) Family relative diversity index, FRDI $(\%)=\left(\mathrm{Ns}_{\mathrm{s}} / \mathrm{T}_{\mathrm{s}}\right) \mathrm{X} 100$

s) Family importance value (FIV) $=$ FRD + FRDI

Where, $\mathrm{S}=$ Total number of species; $\mathrm{H}=$ Shannon-Wiener's diversity index; $\mathrm{N}_{\mathrm{f}}=$ No. of individual in a family; $\mathrm{N}=$ Total no. of individuals of all the species; $P_{i}=($ Number of individuals of one species / Total number of individuals); $\mathrm{T}_{\mathrm{i}}=$ Total number of individuals; $\mathrm{N}_{\mathrm{s}}=$ No. of species; $\mathrm{T}_{\mathrm{s}}=$ Total number of species.

\section{RESULTS AND DISCUSSION}

\section{Seedling status}

A total of 16,166 seedlings of 15 species under 11 families were found in a $3990 \mathrm{~m}^{2}$ area within three salinity zones of Sundarbans. A total of 7723 seedlings of 13 species under 9 families were found in the Low Salinity Zone (LSZ) where Aegiceras comiculatum and Sonneratia apetala was not found. Besides, 5075 seedlings of 15 species under 11 families were found in the Moderate Salinity Zone (MSZ). In addition, a total of 3368 seedlings of 12 species under 9 families were found in the Strong Salinity Zone (SSZ) where Cynometra ramiflora, Rhizophora mucronata, and Sonneratia apetala was not found in the Strong Salinity Zone (SSZ).

About $59 \%$ were represented by one family (Euphorbiaceae) and about $26 \%$ by two families (Rhizophoraceae and Sterculiaceae). Maximum of three species were found in family Rhizophoraceae and two species in Arecaceae and Meliaceae where other families had one species (Table 1). Family Euphorbiaceae showed the highest $(59.59 \%$ ) family relative density followed

Table 1. Family composition, number of species, number of seedlings under each Family, Family relative density (FRD), Familyrelative diversity Index (FRDI), and Family importance value (FIV) index of the seedling in Sundarbans.

\begin{tabular}{lccccc}
\hline Family & No of Species & No of Seedling & FRD (\%) & FRDI (\%) & FIV \\
\hline Euphorbiaceae & 1 & 9634 & 59.59 & 6.67 & 66.26 \\
Rhizophoraceae & 3 & 2565 & 15.87 & 20 & 35.87 \\
Sterculiaceae & 1 & 1677 & 10.37 & 6.67 & 17.04 \\
Meliaceae & 2 & 460 & 2.86 & 13.32 & 16.17 \\
Arecaceae & 2 & 151 & 0.93 & 13.32 & 14.27 \\
Avicenniaceae & 1 & 519 & 3.21 & 6.67 & 9.88 \\
Myrsinaceae & 1 & 495 & 3.06 & 6.67 & 9.73 \\
Fabaceae & 1 & 289 & 1.79 & 6.67 & 8.45 \\
Acanthaceae & 1 & 224 & 1.39 & 6.67 & 8.05 \\
Pteridaceae & 1 & 149 & 0.92 & 6.67 & 7.59 \\
Lythraceae & 1 & 3 & 0.019 & 6.67 & 6.69 \\
\hline Total & $\mathbf{1 5}$ & $\mathbf{1 6 1 6 6}$ & $\mathbf{1 0 0}$ & $\mathbf{1 0 0}$ & $\mathbf{2 0 0}$ \\
\hline
\end{tabular}


by Rhizophoraceae (15.87\%), Sterculiaceae (10.37\%), Avicenniaceae (3.21\%), and Myrsinaceae (3.06\%) (Table 1). Family Rhizophoraceae presented the highest $(20 \%)$ family relative diversity Index (FRDI) followed by Arecaceae $(13.32 \%)$, Meliaceae $(13.32 \%)$ and $6.67 \%$ showed by other families.

Maximum (66.26) family importance value (FIV) showed by Euphorbiaceae followed by Rhizophoraceae (35.87), Sterculiaceae (17.04), Meliaceae (16.17), Arecaceae (14.27), and Avicenniaceae (9.88) (Table 1).

Quantitative characters of Seedling

Among 15 species, one species Excoecaria agallocha embodied 59\% and a total of $85 \%$ was embodied by four species (Excoecaria agallocha $59.60 \%$; Heritiera fomes 10.37\%; Ceriops decandra 8.70\% and Bruguiera sexangula 6.85\%) (Table 2). The Highest (15.273\%) relative frequency (RF) were exposed by Excoecaria agallocha trailed by Heritiera fomes (16.36\%), Ceriops decandra (11.64\%), and Xylocarpus mekongensis (10.182\%) (Table 2). Again Excoecaria agallocha showed the highest $(39.87 \%)$ relative abundance (RA) followed by Aegiceras corniculatum (12.29\%), Bruguiera sexangula (7.70\%), Ceriops decandra (7.64\%), and Heritiera fomes (6.48\%) (Table 2). The maximum importance value index (IVI) has been observed in Excoecaria agallocha (114.74) trailed by Heritiera fomes (33.22), Ceriops decandra (27.98), Bruguiera sexangula (23.64) and Aegiceras corniculatum (17.90) (Table 2). It was found that most of the species were least concert list of IUCN conservation status where Ceriops decandra and Phoenix paludosa were near threatened and Heritiera fomes was listed endangered.

Biological diversity indices for seedling

The mean stem density and species diversity index in the whole survey area was 2701 stem ha-1 $^{-1}$ and 0.0009 correspondingly (Table 3). The ShannonWienner's diversity index was 1.52 where the maximum Shannon-Wienner's diversity index was 2.708 . The Simpson's diversity index and Dominance of simpson index were 0.38 and 0.62 with Simpson's reciprocal index 2.632 (Table 3). The Species evenness index/Pielou evenness index, Menhinick's Index, and Margalef's/Species richness index were 0.561, 0.118, and 1.445 respectively. The values of Shannon-Wienner's, Menhinick's, and Margalef's indices were specified inadequate plant diversity. The Simpson's index revealed that the species were not uniformly distributed and dominated by 3 or 4 tree species (Table 3).

Table 2. Relative Density (RD), Relative Frequency (RF), Relative Abundance (RA), Importance Value Index (IVI), and IUCN (CS) conservation status of the seedling in Sundarbans.

\begin{tabular}{lllllllll}
\hline Scientific name & $\begin{array}{l}\text { Local } \\
\text { name }\end{array}$ & Family & NoS & RD (\%) & RF (\%) & RA (\%) & IVI & $\begin{array}{l}\text { IUCN } \\
\text { CS }\end{array}$ \\
\hline Excoecaria agallocha & Gewa & Euphorbiaceae & 9634 & 59.60 & 15.27 & 39.87 & 114.7 & LC \\
Heritiera fomes & Sundri & Sterculiaceae & 1677 & 10.37 & 16.36 & 6.48 & 33.22 & EN \\
Ceriops decandra & Goran & Rhizophoraceae & 1407 & 8.70 & 11.64 & 7.64 & 27.98 & NT \\
Bruguiera sexangula & kakra & Rhizophoraceae & 1107 & 6.85 & 9.09 & 7.70 & 23.64 & LC \\
Aegiceras corniculatum & Khalshi & Myrsinaceae & 495 & 3.06 & 2.55 & 12.29 & 17.90 & LC \\
Avicennia officinalis & Baen & Avicenniaceae & 519 & 3.21 & 6.55 & 5.01 & 14.77 & LC \\
Xylocarpus mekongensis & Passur & Meliaceae & 296 & 1.83 & 10.182 & 1.84 & 13.85 & LC \\
Cynometra ramiflora & Singra & Fabaceae & 289 & 1.79 & 5.82 & 3.14 & 10.75 & LC \\
Amoora cucullata & Amur & Meliaceae & 164 & 1.01 & 7.64 & 1.36 & 10.01 & DD \\
Acanthus ilicifolius & Hargoza & Acanthaceae & 224 & 1.39 & 4.00 & 3.54 & 8.93 & LC \\
Acrostichum aureum & Tigerfurn & Pteridaceae & 149 & 0.92 & 1.82 & 5.18 & 7.92 & LC \\
Phoenix paludosa & Hantal & Arecaceae & 92 & 0.57 & 4.36 & 1.33 & 6.27 & NT \\
Nypa fruticans & Golpata & Arecaceae & 59 & 0.36 & 3.27 & 1.14 & 4.78 & LC \\
Rhirophora mucronata & Jhana & Rhizophoraceae & 51 & 0.32 & 1.09 & 2.96 & 4.36 & LC \\
Sonneratia apetala & Keora & Lythraceae & 3 & 0.019 & 0.36 & 0.52 & 0.91 & LC \\
\hline & & Total & 16,166 & 100 & 100 & 100 & 300 & \\
\hline
\end{tabular}


Table 3. Different biological diversity indices for seedlings in Sundarbans.

\begin{tabular}{ll}
\hline Parameter & Total \\
\hline Total Area $\left(\mathrm{m}^{2}\right)$ & 3990 \\
Mean Density $\left(\mathrm{stem} \mathrm{ha}^{-1}\right)$ & 2701 \\
Species diversity index & 0.0009 \\
Shannon-Wienner's diversity index & 1.52 \\
Shannon's maximum diversity index & 2.708 \\
Simpson's diversity index & 0.38 \\
Dominance of simpson index & 0.62 \\
Simpson's reciprocal index & 2.632 \\
Species evenness index/Pielou evenness index & 0.561 \\
Menhinick's Index & 0.118 \\
Margalef's/Species richness index & 1.445 \\
\hline
\end{tabular}

Biological diversity indices of three salinity zones

The total number of seedlings and mean density for Low Salinity Zone (LSZ), Moderate Salinity Zone (MSZ), and Strong Salinity Zone (SSZ) were 7723 and 4466 stem ha- $^{-1}, 5075$ and 2543 stem ha $^{-1}$ and 3368 and 2110 stem $\mathrm{ha}^{-1}$ separately (Table 4). The Species diversity index of the three salinity zones were $0.0017,0.0029$, and 0.0035 respectively. The Shannon-Wienner's diversity index of LSZ, MSZ, and SSZ were $0.887,1.369$, and 1.845 with Shannon's maximum diversity index were $2.565,2.708$, and 2.485 correspondingly (Table 4). LSZ (0.632) showed the highest Simpson's diversity index followed by MSZ (0.394) and SSZ (0.21). The Dominance of Simpson's index and Simpson's reciprocal index were LSZ (0.368 and 1.582), MSZ (0.606 and 2.538), and SSZ (0.79 and 4.762) separately. The Species evenness index/Pielou evenness index for LSZ, MSZ, and SSZ were 0.346, 0.505 and 0.742 where Menhinick's Index were 0.148, 0.210, and 0.207 respectively (Table 4). The Margalef's/Species richness index for LSZ, MSZ, and SSZ were $1.452,1.758$, and 1.477 correspondingly. The mean density explored a higher number of individuals but diversity indices indicated lower diversity in all three salinity areas near localities. That's mean the forest was converted and dominated by only three or four species.

Table 4. Different biological diversity indices for three salinity zones of Sundarbans.

\begin{tabular}{llll}
\hline Parameter & LSZ & MSZ & SSZ \\
\hline Total Area $\left(\mathrm{m}^{2}\right)$ & 1330 & 1330 & 1330 \\
Compartment No & $1,2,3,4,5,7,24,28$ & $15,21,30,31,32,35,36,37,38$ & 46,47 \\
Total Number of Seedlings & 7723 & 5075 & 3368 \\
Mean Density (stem ha $\left.{ }^{-1}\right)$ & 4466 & 2543 & 2110 \\
Species diversity index & 0.0017 & 0.0029 & 0.0035 \\
Shannon-Wienner's diversity index & 0.887 & 1.369 & 1.845 \\
Shannon's maximum diversity index & 2.565 & 2.708 & 2.485 \\
Simpson's diversity index & 0.632 & 0.394 & 0.21 \\
Dominance of simpson index & 0.368 & 0.606 & 0.79 \\
Simpson's reciprocal index & 1.582 & 2.538 & 4.762 \\
Species evenness index & 0.346 & 0.505 & 0.742 \\
Menhinick's Index & 0.148 & 0.210 & 0.207 \\
Margalef's/Species richness index & 1.452 & 1.758 & 1.477 \\
\hline
\end{tabular}


Discussion

Sundarbans has very rich floristic diversity compared to other mangrove forests of the world where half of the total number of mangrove species found in the world occurs in the Sundarbans (Bangladesh and Indian Sundarbans) (Patil 1962). But this study revealed the poor forest condition of Sundarbans Mangrove Forest (SMF) and about 59\% comprised of one species (Excoecaria agallocha) where about $85 \%$ comprised of four species (Excoecaria agallocha, Heritiera fomes, Ceriops decandra, and Bruguiera sexangula). Excoecaria agallocha was increased in a highly disturbed area of Sundarbans because its leaves were poisonous and not suitable for grazing. A total of 15 species were found which was higher than the mangrove swamp forest in southern Nigeria (Asuk et al. 2018) and lower than Puerto Princesa Bay (Dangan-Galon et al. 2016) and some other studies carried out in whole Sundarbans (Hossain 2003, Rashid et al. 2008, Saiful et al. 2014, Saiful et al. 2015). The SMF was predominated by Euphorbiaceae and Rhizophoraceae and the dominancy of Rhizophoraceae was also found by (Asuk et al. 2018; Igu et al. 2017; Ogar \& Asuk 2015). The total number of species found in this study was lesser than other forests of Bangladesh (Hossen et al. 2021; Malaker et al. 2010; Motaleb \& Hossain 2011; Rahaman et al. 2020). This poor forest condition may be the effect of natural and anthropogenic disturbance whereas most of the people are dependent on Sundarbans for their livelihood directly or indirectly (Islam 2019). They entered these areas for collecting fuel, fodder, fruits, golpata, and so on through legal permission of the authorities but they are doing this hamper in their subconscious mind or intentionally. Islam et al. (2020) stated that most of the villagers adjacent to Sundarbans collect fish, honey, golpata, fuel wood, hogla, prawn, hantal, crab, nall, keora fruit, malia, goran stick, shrimp fry, and medicinal plants from Sundarbans but only $31.11 \%$ respondents had equipment facilities. Besides this, the government has declared officially the Sundarbans as a pirate-free area in 2018 which improved the destination's image perception to tourists (Haque et al. 2016) which affects diversity negatively. Besides, Sonneratia apetala was found only Moderate Salinity Zone (MSZ) because of high palatability and collection of Sonneratia apetala seeds for making pickles, it was declined drastically.

The average mean density was $2701 \mathrm{stem} \mathrm{ha}^{-1}$ where a maximum of

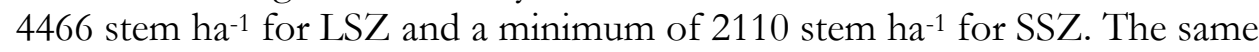
rich density was found in Puerto Princesa Bay, Palawan Island, Philippines (Dangan-Galon et al. 2016). The density of SMF was higher than other forest parts of Bangladesh (Motaleb \& Hossain 2011; Rahaman et al. 2020).

The Shannon-Wienner's diversity index (1.52), Simpson's diversity index (0.38), Margalef's value (1.445), and Species evenness index (0.561) were lower than Akpabuyo mangrove and the mangrove swamp forest in southern Nigeria (Olowokudejo \& Oyebanji 2016; Asuk et al. 2018). But the Simpson's diversity index (0.38) in this study was higher than (Dey \& Akther 2020; Hossen et al. 2019; Hossen et al. 2021) which indicated the lower diversity in SMF than other parts of Bangladesh. The values of Menhinick's (0.118) and Margalef's (1.445) indices designated the limited plant diversity in SMF.

The species richness of this study advocated that many plant species represented by few families may lead to the extinction of many of the species in SMF. The opposite result was found by (Olowokudejo \& Oyebanji 2016) in southeastern Nigeria. Species evenness index (0.561) was lower than natural sal forest (0.8) (Rahaman et al. 2020), South Eastern Bangladesh (0.613) (Dey \& Akther 2020), Himchari National Park (HNP) (0.853) (Hossen et al. 2019) that indicated the less equitable distribution of understory vegetation in SMF. 
In this analysis, it was found that the number of seedlings and mean density gradually decreased with the increase of salinity. The highest number (7723 stem) and mean density (4466 stem ha-1) were found in LSZ in the same area of $1330 \mathrm{~m}^{2}$ followed by MSZ (5075 stem, $2543 \mathrm{stem} \mathrm{ha}^{-1}$ ) and SSZ (3368 stem, 2110 stem ha $\left.^{-1}\right)$. The Shannon-Wienner's diversity index (0.887, 1.369 , and 1.845) was steadily increased and Simpson's diversity index $(0.632$, 0.394 , and 0.21 ) was gradually decreased from LSZ to MSZ and SSZ.

Simpson's diversity index indicated that the diversity was higher in SSZ than in the other two zones. The highest species evenness was found in SSZ (0.742) where LSZ showed the lowest (0.346). The Menhinick's Index and Margalef's/Species richness index of all three zones indicated the lower diversity but the value was various with the location. It may be the effect of salinity in water and soil, inundation type, time and duration, grazing, erosion, etc. that is observed during field data collection. But the suggested hypothesis of Ball (1998) was the opposite of this observation; he denied the effect of salinity (water and soil) on diversity declination. All these variables may affect the germination and survival rate of species. Further research needs to identify the degree of effect of these factors in SMF.

It was found that most of the species were on the least concerned list of IUCN conservation status where Ceriops decandra and Phoenix paludosa were near threatened and Heritiera fomes was listed endangered. It indicated that this area only consisted of abundant least concern species like Excoecaria agallocha, Bruguiera sexangula, Aegiceras corniculatum, Avicennia officinalis, and Xylocarpus mekongensis. Anthropogenic factors, grazing, tourism, increased number of water vehicles, and excessive extraction of food, fodder, and fuel wood with various natural calamities may affect the diversity and richness of species. Helal Siddiqui and Islam (2019) were recommended that the sustainable enrichment plantation will be carried out which showed satisfactory growth and survivability to improve the species richness of these areas. This study had many limitations like differences in methods of study, the intensity of sampling, area covered, habitat types, and plot size used which may affect species richness obtained by other studies (Hossain 2003, Rashid et al. 2008, Saiful et al. 2014, Saiful et al. 2015).

\section{CONCLUSION}

The natural regeneration status of forests is very vital for the sustainable management of forests and forest resources. Bangladesh is still lucky to have a high percentage of forest cover in the Sundarbans Reserve Forest (SRF). However, this rich forest is decreasing with time particularly near human habitation to meet the basic needs of fuel, fodder, and small timber where the degree of causes is still unknown. The study will provide quantitative information about the seedling composition which may be very helpful for understanding the Sundarbans Mangrove Forest. The analysis showed poor diversity indices and the forest was dominated by few species with few families. It was recommended that the sustainable enrichment plantation will be carried out to improve the species richness of these areas. The Forest Department is concerned and to lessen this situation has designed comanagement committees as well as providing alternative livelihoods to the Sundarbans user groups in cooperation with local NGOs. The study may be supportive and pave the way for advanced research on regeneration potentials of the mangrove species for safeguarding and heightening forests in the future. 


\section{AUTHORS CONTRIBUTION}

A.S.M.H.S. and M.N.S.P. conceived the study, A.S.M.H.S., M.N.S.P., M.M.R., M.A.I., and S.M.M.H. participated in field survey, M.N.S.P. analyzed data and wrote the first draft, and all authors revised the manuscript.

\section{ACKNOWLEDGMENTS}

The authors are grateful and thanks to all staff of the Mangrove Silviculture Division, Bangladesh Forest Research Institute for providing care in field data collection, compilation, and analysis.

\section{CONFLICT OF INTEREST}

The authors declare no conflicting interests.

\section{REFERENCES}

Alongi, D.M., 2002. Present State and Future of the World's Mangrove Forests. Environmental Conservation, 29(3), pp.331-349.

Asuk, S.A. et al., 2018. Species Composition and Diversity of Mangrove Swamp Forest in Southern Nigeria. International International Journal of Avian \& Wildlife Biology, 3(2), pp.159-164.

Badola, R. \& Hussain, S.A., 2005. Valuing Ecosystem Functions: An Empirical Study on the Storm Protection Function of Bhitarkanika Mangrove Ecosystem, India. Environmental Conservation, 32(1), pp.85-92.

Ball, M., 1998. Mangrove Species Richness in Relation to Salinity and Waterlogging: A Case Study Along the Adelaide River Floodplain, Northern Australia. Global Ecology and Biogeography Letters, 7(1), pp.73-82.

Biswas, S.R. \& Misbahuzzaman, K., 2008. Tree Species Diversity and Regeneration Traits of the Dominant Species in a Dipterocarp Forest in Bangladesh: Implications for Conservation. International Journal of Biodiversity Science and Management, 4(2), pp.81-91.

Cannon, C.H. et al., 1998. Tree Species Diversity in Commercially Logged Bornean Rainforest. Science, 281(5381), pp.1366-1368.

Chaffey, D.R. et al., 1985, Sundarbans Forest Inventory Project, Bangladesh. A glossary of vernacular plant names and a field key to the trees, Overseas Development Administration, England, p.23.

Chowdhury, Q.I., 2001, Bangladesh: State of Bio-Diversity Forum of Environmental Journalists of Bangladesh (FEJB), Shegun Bagicha, Dhaka, Bangladesh.

Clifford, H.T. \& Stephenson, W., 1975, An Introduction to Numerical Classification, Academic Press.

Dangan-Galon, F. et al., 2016. Diversity and Structural Complexity of Mangrove Forest along Puerto Princesa Bay, Palawan Island, Philippines. Journal of Marine and Island Cultures, 5(2), pp.118-25.

Danielsen, F., et. al. 2005. The Asian Tsunami: A Protective Role for Coastal Vegetation. Science, 310(5748), p.643.

Dey, A. \& Akther, A., 2020. Tree Species Composition and Natural Regeneration Status of Southeast Region of Bangladesh. Journal of Tropical Biodiversity and Biotechnology, 5(1), p.27.

Dey, T. et al., 2020. Attitudes of Local People towards Community Based Eco-Tourism in the Sundarbans. International Journal of Business, Management and Social Research, 9 (2), pp.528-535.

Dogra, K.S. et al., 2009. Impact of Ageratum Conyzoides L. on the Diversity and Composition of Vegetation in the Shivalik Hills of Himachal Pradesh (Northwestern Himalaya), India. International Journal of Biodiversity and Conservation, 1(5), pp.135-145. 
Feroz, S.M. et al., 2014. Community Ecology and Spatial Distribution of Trees in a Tropical Wet Evergreen Forest in Kaptai National Park in Chittagong Hill Tracts, Bangladesh. Journal of Forestry Research, 25, pp.311-318.

Field, C.D., 1995, Journey amongst Mangroves, International Society for Mangrove Ecosystems (ISME).

Forest Department, 2010. Integrated Resources Management Plans for the Sundarbans. Ministry of Environment and Forests: Dhaka, Bangladesh 1: 1-281.

Hall, J.B. \& Swaine, M.D., 1976. Classification and Ecology of ClosedCanopy Forest in Ghana. The Journal of Ecology, 64(3), pp.913-951.

Haque, S.M.S. \& Alam, M.S., 1988. Some Aspects of Practicing the Clearfelling Followed by Artificial Regeneration System in the Cox's Bazar Forest Division (Bangladesh). Chittagong University Studies, Part II: Science, 12(2), pp.87-95.

Haque, M.Z. et al., 2016. Discovery of a potential site for community-based sustainable ecotourism in the Sundarbans reserve forests, Bangladesh. International Journal of Conservation Science, 7(2), pp.553-566.

Hasan, M.K. \& Alam, A.A., 2006. Land Degradation Situation in Bangladesh and Role of Agroforestry. Journal of Agriculture \& Rural Development, 4(1), pp.19-25.

Heining, R.L., 1892, Working Plan of Sundarbans Government Forest, Khulna and 24-Pargana District, Bengal, Calcutta, Bengal Secretariat Press.

Helal Siddiqui, A.S.M., 2009, Sundarban V romon O Sundarban V romon Prosongo (Sundarbans and Visit to the Sundarbans), Published by Angikar Prokashoni, 38 Bangla Bazar, Dhaka.

Helal Siddiqui, A.S.M. \& Islam, M.A., 2019. Survivality and Growth Performance of Jarul (Lagerstroemia Speciosa) in the Raised Land of Less Saline Water Zone in the Sundarbans. International Journal of Agriculture Innovations and Research, 8(2), pp.144-50.

Hossain, A.B.M.E., 2003. The undergrowth species of Sundarban mangrove forest ecosystem (Bangladesh). The final report on Sundarban Biodiversity Conservation Project, IUCN, Dhaka, Bangladesh (unpublished).

Hossain, M. et al., 2004. Comparative Regeneration Status in a Natural Forest and Enrichment Plantations of Chittagong (South) Forest Division, Bangladesh. Journal of Forestry Research, 15(4), pp.255-60.

Hossain, M. et al., 2015. Composition and Diversity of Tree Species in Kamalachari Natural Forest of Chittagong South Forest Division, Bangladesh. Journal of Forest and Environmental Science, 31(3), pp.192-201.

Hossain, M.A. et al., 2013. Natural Regeneration Potential of Native Tree Species in Dudhpukuria-Dhopachori Wildlife Sanctuary of Chittagong, Bangladesh. Bangladesh Journal of Forest Science, 33(2), pp.15-25.

Hossain, M.A. et al., 2018. Quantifying Diversity and Composition of Tree Species in Satchari. International Journal of Forest Usufructs Management, 19, pp.15-23.

Hossain, M.K. et al., 1999. Assessment of Natural Regeneration Status in a Mixed Tropical Forest at Kaptai of Chittagong Hill Tracts (South) Forest Division. The Chittagong University J. Science, 23(1), pp.73-79.

Hossain, M.K., 2001, Overview of the Forest Biodiversity in Bangladesh. Assessment, Conservation, and Sustainable Use of Forest Biodiversity (CBD Technical Series No. 3), Montreal, SCBD, Secretariat of the Convention on Biological Diversity, Canada.

Hossain, M.K. et al., 2020. Diversity and Conservation Status of Tree Species in Hazarikhil Wildlife Sanctuary (HWS) of Chittagong, Bangladesh. Geology, Ecology, and Landscapes, 4(4), pp.298-305. 
Hossen, S. et al., 2019. Restoration and Rehabilitation Potential of the Remnant Natural Forests of Himchari National Park (HNP) in Cox's Bazar, Bangladesh. Asian Journal of Forestry, 3(1), pp.25-30.

Hossen, S. et al., 2021. Quantitative Assessment of Tree Species Diversity of Himchari National Park (HNP) in Cox's Bazar, Bangladesh. Asian Journal of Forestry, 5(1), pp.1-7.

Huston, M.A., 1994, Biological Diversity: The Co-Existence of Species on Changing Landscape, Cambridge University Press, Cambridge, p.681.

Igu, N.I. et al., 2017. Biodiversity and Carbon Potentials of a Nigerian Forest Reserve: Insights from the Niger Basin. Journal of Environmental Protection, 8, pp.914-922.

Islam, M. A., 2019. Status of Social Forestry for the Socio-Economic Development in the Coastal Belt of Sundarban. International Journal of Agriculture Innovations and Research, 8(3), pp.252-263.

Islam, A. et al., 2020. Utilization of Minor Forest Products of the Sundarbans in Bangladesh. Advances in Agriculture, Horticulture and Entomology: AAHE-126, 2020(4), pp.1-8.

Karim, A., 1994, 'Vegetation', in Z. Hussain \& G. Acharya (eds.), Mangroves of the Sundarbans. Volume Two: Bangladesh, pp.43-75, IUCN, Bangkok, Thailand.

Kathiresan, K. \& Rajendran, N., 2005. Coastal Mangrove Forests Mitigated Tsunami. Estuarine, Coastal and Shelf Science, 65(3), pp.601-606.

Keenan, R.J. et al., 2015. Dynamics of Global Forest Area: Results from the FAO Global Forest Resources Assessment 2015. Forest Ecology and Management, 352, pp.9-20.

Kent, M. \& Coker, P., 1992, Vegetation Description and Analysis: A Practical Approach, John Wiley and Sons, NY, USA, pp.167-169.

Khan, S.M.M.H. et al., 2008. In: Biodiversity Conservation in Bangladesh. Encyclopedia of Flora of Bangladesh (Ahmed ZU, Begum ZNT, Hassan MA, Khondker M, Kabir SMH, Ahmed M, Ahmed ATA, Rahman AKA, Haque EU (Eds.). Bangladesh Profile. Asiatic Society of Bangladesh, Dhaka 1: 9-19.

Laurance, W.F. et al., 1998. Rain Forest Fragmentation and the Dynamics of Amazonian Tree Communities. Ecology, 79(6), pp.2032-2040.

Malaker, J.C. et al., 2010. Floristic Composition of Lawachara Forest in Bangladesh. Intl J Expt Agric, 1(2), pp.1-9.

Malik, A. et al., 2014. Species Richness and Diversity Along The Disturbance Gradient In Kedarnath Wildlife Sanctuary And Its Adjoining Areas In Garhwal Himalaya, India. International Journal of Current Research, 6(12), pp.10918-10926.

Malik, Z.A. \& Bhatt, A.B., 2016. Regeneration Status of Tree Species and Survival of Their Seedlings in Kedarnath Wildlife Sanctuary and Its Adjoining Areas in Western Himalaya, India. Tropical Ecology, 57(4), pp.677-690.

Margalef, R., 1958. Changes in Carbon Storage in Fallow Forest. Forest Ecology and Management, 183, pp.61-75.

Mazda, Y. et al., 1997. Mangroves as a Coastal Protection from Waves in the Tong King Delta, Vietnam. Mangroves and Salt Marshes, 1(2), pp.127-135.

Miah, M.D. et al., 1999. Study on the Natural Regeneration of Pitraj (Aphanamixis Polystachya Wall. and Parker) in the Plantations of Chittagong University Campus. Chittagong Univ. J. Sci, 23(2), pp.125127.

Michael, P., 1990, Ecological Methods for Field and Laboratory Investigation, Tata McGrew Hill Publishing Co. Ltd., New Delhi, India, pp.404-424. 
Mittermeier et al., 1998. Biodiversity Hotspots and Major Tropical

Wilderness Areas: Approaches to Setting Conservation Priorities.

Conservation Biology, 12(3), pp.516-520.

Motaleb, M.A. \& Hossain, M.K., 2007. Studies on Natural Regeneration of a Semi-Evergreen Forest of Chittagong (South) Forest Division, Bangladesh. J. Forestry \& Environments, 5, pp.95-101.

Motaleb, M.A. \& Hossain, M.K., 2011. Assessment of Tree Species Diversity of Tankawati Natural Forests, Chittagong (South) Forest Division, Bangladesh. Eco-Friendly Agric J., 4(2). pp.542-545.

Nebel, G. et al., 2001. Structure and Floristic Composition of Flood Plain Forests in the Peruvian Amazon I. Overstorey. Forest Ecology and Management, 150(1-2), pp.27-57.

Nishat, A. et al., 2002, Bioecological Zones of Bangladesh, The World Conservation Union (IUCN) Country Office, Dhaka, Bangladesh.

Odum, E.P. \& Gary, W.B., 1971, Fundamentals of Ecology, Third Edition, Thomson, Brooks/Cole.

Ogar, D.A. et al., 2015. Forest Cover Change in Stubb's Creek Forest Reserve Akwa Ibom State, Nigeria. Applied Tropical Agriculture, 21(2), pp.183-189.

Olowokudejo, J.D. \& Oyebanji, O.O., 2016. Floral Diversity of the Littoral Vegetation of Southeastern Nigeria. International Journal of Biodiversity and Conservation, 8(12), pp.320-333.

Paolini, J.E. \& Sánchez-Arias, L.E., 2008, 'Comparative Biochemical Study of the Rhizosphere of Rhizophora Mangle and Its Associated Species Cyperus Sp. in the Ciénaga de Soledad (Colombia)' in Lieth H., Sucre M.G., Herzog B. (eds.), Mangroves and Halophytes: Restoration and Utilisation, Tasks for Vegetation Sciences, vol 43. Springer, Dordrecht.

Patil, R.P., 1962. Our Mangrove Resources. Tropical Ecology, $3(1$ \& 2), pp.70-1. Pielou, E.C., 1995, 'Biodiversity versus Old-Style Diversity Measuring for Conservation' in: Boyle T.J.B., Boontawee B. (eds.), Measuring and Monitoring Biodiversity in Tropical and Temperate Forests, pp.5-17, Proceedings of an IUFRO Symposium Held at Chiang Mai, Thailand in 1994, CIFOR, Indonesia.

Prain, D., 1903. The Flora of Sundarbans: Records of the Botanical Survey of India, Periodical Expert Book Agency, Delhi, 114, pp.231-370.

Rahaman, M.T. et al., 2020. Comparative Study of Understory Between Exotic Monoculture Plantation (Acacia Sp.) and Adjacent Natural Sal (Shorea Robusta) Forest. European Journal of Agriculture and Food Sciences, 2(6).

Rahman, M.A. et al., 2000. Diversity, Ecology, Distribution and Ethnobotany of the Apocynaceae of Bangladesh. Bangladesh J Plant Taxon, 7(2), pp.57 -76 .

Rahman, M.H. et al., 2011. Assessment of Natural Regeneration Status and Diversity of Tree Species in the Biodiversity Conservation Areas of Northeastern Bangladesh. Journal of Forestry Research, 22(4), pp.529-554.

Rashid, S.H. et al., 2008. Undergrowth species diversity of Sundarban mangrove forest (Bangladesh) in relation to salinity. Ber. Inst. Landschafts -Pflanzenokologie Univ. Hohenheim Heft, 17, S.41-56.

Richards, P.W., 1963. Ecological Notes on West African Vegetation III. The Upland Forests of Cameroons Mountain. Journal of Ecology, 51(3), pp.529-554. 
Saiful, I. et al., 2014, 'Plant Diversity and Forest Structure of the Three Protected Areas (Wildlife Sanctuaries) of Bangladesh Sundarbans: Current Status and Management Strategies' in: F. Hanum et. al. (eds.), Managrove Ecosystem of Asia, pp.127-152, London \& New York: Springer.

Saiful, I. et al., 2015, Biodiversity Survey Flora: Technical Report, Sundarban Environmental and Livelihoods Security Project, Forest Department, Dhaka, Bangladesh.

Seidensticker, J. \& Hai, M.A., 1983, The Sundarbans Wildlife Management Plan: Conservation in the Bangladesh Coastal Zone, IUCN, Gland, 120.

Shannon, C.E., 1948. A Mathematical Theory of Communication. Bell System Technical Journal, 27(3), pp. 379-423.

Sharma, C.M. et al., 2014. Assessment of Forest Structure and Woody Plant Regeneration on Ridge Tops at Upper Bhagirathi Basin in Garhwal Himalaya. Tropical plant research, 1(3), pp.62-71.

Shukla, R.S. \& Chandal, P.S., 2000, Plant Ecology and Soil Science (9thEdn.), Ramnagar. S. Chand and Company Limited, New Delli, India, pp.121376.

Simpson, E.H., 1949. Measurement of Diversity [16]. Nature, 163(688).

Sobuj, N.A. \& Rahman, M., 2011. Assessment of Plant Diversity in Khadimnagar National Park of Bangladesh. International Journal of Environmental Sciences, 2(1), p.79.

Tomlinson, P.B., 1986. The Botany of Mangroves. The Botany of Mangroves, 42 (4), pp.956-957.

Whittaker, R.H., 1977, 'Evolution of Species Diversity in Land Communities' in M.K. Hecht and B.W.N.C. Steere (eds.), Evolutionary Biology, pp.1-67, Plenum Press, New York. 